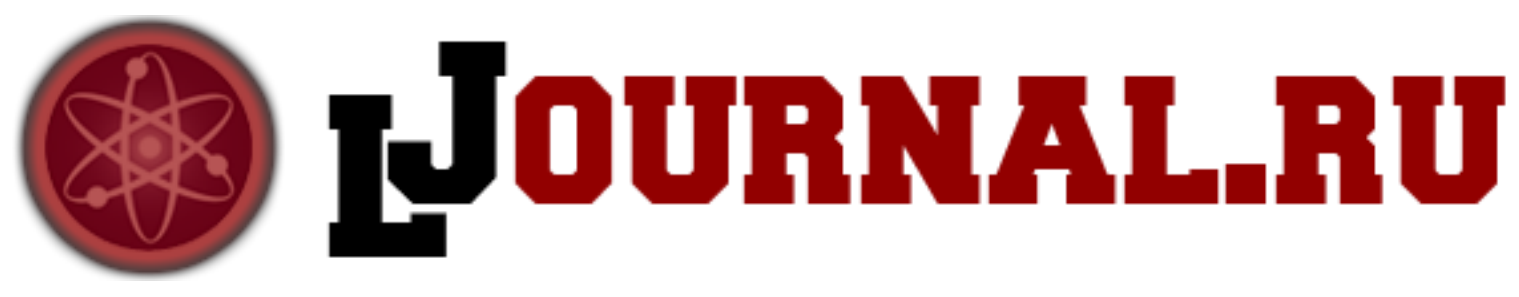

Гасанов А.К.

Астраханский государственный университет Астрахань, Россия

doi: 10.18411/1j2016-1-06

\title{
Закон об ОСАГО: достоинства и недостатки в свете последних изменений
}

1 июля 2003 года в Российской Федерации был введен в действие Федеральный закон от 25 апреля 2002 г. № 40-Ф3 «Об обязательном страховании гражданской ответственности владельцев транспортных средств» (Закон об ОСАГО) ${ }^{1}$, основной целью которого является охрана прав потерпевших на возмещение вреда, которое причинено их жизни, здоровью, а также имуществу при ДТП. Таким образом, с этого дня в Российской Федерации договоры об обязательном страховании гражданской ответственности владельцев транспортных средств должны заключаться в обязательном порядке. Законодательством Российской Федерации установлены правовые и организационные основы обязательного страхования автогражданской ответственности с целью защиты имущественных и неимущественных прав потерпевших в результате ДТП ${ }^{2}$.

Так как растет количество происшествий с участием транспорта на дорогах, неизбежна организация страхования ответственности владельцев автомобильного транспорта. Только за январь-февраль 2015 года в России произошло 79199 дорожно-транспортных происшествий³. Эта проблема

\footnotetext{
${ }^{1}$ Собрание законодательства Российской Федерации. 2002. № 18. Ст. 1720.

2 Биккинин И.А., Шакирова М.Л., Костырева В.А. Страхование автогражданской ответственности: состояние и пути развития // Транспортное право. 2005. № 2. С. 3.

${ }^{3}$ http://www.1 gai.ru/
} 
подробно исследуется в последнее время многими теоретиками и практиками ${ }^{4}$. Немало статей посвящено именно целесообразности внесения изменений и дополнений в Закон об ОСАГО, его основным достоинствам и недостаткам. Поэтому наше исследование должно, прежде всего, исходить из рассмотрения теоретических аспектов и их применения на практике.

Обязательное страхование автогражданской ответственности ранее являлось добровольным до дня вступления в силу Закона об ОСАГО. При этом возможность применения института добровольного страхования автогражданской ответственности остается и сейчас. Так, владелец транспортного средства имеет право, помимо обязательного страхования, в добровольном порядке достраховать свою гражданскую ответственность на случай недостаточности страховой выплаты по обязательному страхованию. Об этом говорится в пункте 5 статьи 4 Закона об ОСАГО 5 .

В 2014 г. Закон об ОСАГО подвергся серьезным и кардинальным нововведениям, которые произошли в июле, вступили / вступают в силу с 2 августа 2014 г., 1 сентября 2014 г., 1 октября 2014 г., 1 апреля 2015 г., 1 июля 2015 г. и 1 октября 2019 г. Такая своеобразная пятилетка поэтапных изменений.

Для исследования указанной темы необходимо рассмотреть основные, на наш взгляд, положительные моменты произошедших изменений в Законе об ОСАГО, которые можно считать его достоинствами.

\section{1. Повышение сумм денежного возмещения вреда здоровью и имуществу.}

Обязательное страхование автогражданской ответственности дает возможность находить решение в вопросе возмещения вреда потерпевшим. Изменения в Закон коснулись выплат по страховым случаям. Размер компенсаций по жизни и здоровью пострадавших в ДТП составляет не 160 тысяч рублей, а 500 тыс. рублей с 1 апреля 2015 г. Также в случае смерти

\footnotetext{
${ }^{4}$ Биккинин И.А., Шакирова М.Л., Костырева В.А. Страхование автогражданской ответственности: состояние и | пути развития // Транспортное право. 2005. № 2. С. 3.

${ }^{5}$ Сокол П.В. Обязательное страхование гражданской ответственности владельцев транспортных средств: научно| практическое пособие. М.: Деловой двор, 2013. С. 4.
} 
пострадавшего право на возмещение имеют: супруг, дети, родители потерпевшего. Сумма возмещения составит 475 тысяч рублей. По имуществу каждого потерпевшего величина компенсации составляет 400 тысяч рублей с 1 октября 2014 г.

Также, увеличился предельный размер выплат по евро-протоколу. Европротокол - это такая схема оформления ДТП, которая проходит без вызова сотрудников ГИБДД, допустимая при соблюдении следующих обстоятельств:

1. Вследствие ДТП вред был причинен только имуществу, вред жизни и здоровью людей причинен не был;

2. ДТП случилось с участием двух транспортных средств;

3. Отсутствуют разногласия между участниками аварии.

Сейчас, согласно евро- протоколу, можно получить выплату до 50 тысяч рублей. Ранее предельный размер выплат был ограничен 25 тысяч рублей.

2. Также достоинством Закона можно считать то, что владелец TC mеnерь может предпочесть одну из двух форм возмещения по страховому полису или денежную выплату, или оплату ремонта транспорта на станции технического обслуживания. При всем этом страховые компании сейчас должны размещать на своих сайтах список автосервисов, с которыми у них заключены соглашения на обслуживание авто по страховке.

3. Третьим положительным нововведением является сокращзение срока выполнения выплат по страховым полисам или выдача направления на ремонт транспортного средства с указанием срока ремонта, либо направление потерпевшему мотивированного отказа в страховой выплате в течение 20 рабочих дней вместо 20, предусматривавшихся ранее (ст. 12 Закона).

4. Повыпение пени за просроченную выплату со стороны страховой компании. В случае несоблюдения срока исполнения страховой выплаты или компенсации причиненного вреда в натуре страховщик за каждый день просрочки оплачивает потерпевшему неустойку в размере 1 \% от установленного в соответствии с Законом размера страховой выплаты по виду 
причиненного вреда каждому потерпевшему. В случае нарушения срока направления потерпевшему обоснованного отказа в страховом возмещении страховщик за каждый день просрочки уплачивает потерпевшему денежные средства в виде финансовой санкции в размере 0,05 \% от определенной Законом страховой суммы по виду причиненного вреда каждому потерпевшему.

5. Увеличение компенсации за поврежденные детали. В свете данных изменений пострадавшему владельцу ТС будет компенсироваться не менее $50 \%$ стоимости поврежденной детали, но не 20\%, как это было ранее.

6. С 01.07.2015 введен электронный полис ОСАГО. Положительной стороной данного нововведения можно считать исключение возможности его фальсификации.

7. За прямым возмещением убытков теперь нужно обращцаться только в mу страховую компанию, с которой заключен договор. Страховщик теперь не сможет отправить потерпевшего к другой страховой компании, как это было раньше, когда обращаться можно было, в том числе, и в компанию виновника ДТП.

Безусловно, все вышеперечисленные изменения выгодны автовладельцам. А что можно отнести к недостаткам Закона? Разумеется это, прежде всего:

1. Значительное повышение стоимости полиса ОСАГО. Примерно полис ОСАГО на легковой автомобиль, принадлежащий физическому лицу, стал дороже на $45-60 \%$.

2. Возможен рост числа отказов в выплатах из-за неправильно оформленного извещения о ДТП, в отсутствие представителей закона на месте происшествия. Поэтому считаем, что для поднятия правовой культуры автолюбителей необходимо разъяснить правила заполнения извещения о ДТП.

Бесспорно, появление института ОСАГО определено социально экономическими тенденциями, связанными с повышением автомобилизации, напряженности дорожного движения, ростом ДТП, несчастных случаев и количества потерпевших, увеличением материальной ответственности 
физических и юридических лиц за результаты своих действий, причинением немалого ущерба экономике страны в целом. Данные обстоятельства, являясь общемировой тенденцией, говорят о том, что и в России ОСАГО будет занимать более важное место среди иных сфер страхования ${ }^{6}$. В итоге можно сказать, что новая редакция закона об ОСАГО, принятая в июле 2014 года несет для автовладельцев в основном больше положительных сторон, чем негативных.

6 Глинка В.И., Ручкин О.Ю., Трунцевский Ю.В. Обязательное страхование гражданской ответственности владельцев транспортных средств: теоретические и практические аспекты: научно-практическое пособие. М.: Юрист, 2013. С. 5 


\section{Литература:}

1. Федеральный закон от 25. 04. 2002 № 40-Ф3 (ред. от 04.11.2014) «Об обязательном страховании гражданской ответственности владельцев транспортных средств» // Собрание законодательства РФ, 06.05.2002, № 18, ст. 1720.

2. Закон РФ от 27.11.1992 № 4015-1 ( ред. от 28.12.2013) «Об организации страхового дела в Российской Федерации» // Российская газета, № 6, 12.01.1993г.

3. Постановление Пленума Верховного Суда РФ от 26 января 2010 г. № 1 «О применении судами гражданского законодательства, регулирующего отношения по обязательствам вследствие причинения вреда жизни или здоровью гражданина» вред считается причиненным источником повышенной опасности, если он явился результатом его действия или проявления его вредоносных свойств» // Бюллетень Верховного Суда Российской Федерации. 2010. № 3.

4. Биккинин И.А., Шакирова М.Л., Костырева В.А. Страхование автогражданской ответственности: состояние и пути развития // Транспортное право. 2005. № 2.С 3.

5. Сокол П.В. Обязательное страхование гражданской ответственности владельцев транспортных средств: научно-практическое пособие. М.: Деловой двор, 2013. 169 с.С. 4.

6. Глинка В.И., Ручкин О.Ю., Трунцевский Ю.В. Обязательное страхование гражданской ответственности владельцев транспортных средств: теоретические и практические аспекты: научно-практическое пособие. М.: Юрист, 2013. 145 с. С.1.

7. Редькин Г.Е. ОСАГО - неутешительная картина с нерадующей перспективой // Имущественные отношения в Российской Федерации. 2012. № 12. С. 6. 